\title{
Abdication of Personal Responsibility
}

In the plays discussed in the previous chapter, characters quite literally find themselves forced to flee to survive, but nevertheless discover that there is no escape from the responsibility to confront evil. In both Der öffentliche Ankläger and Meier Helmbrecht. Frei nach Wernher dem Gärtner, characters seek to evade this very responsibility, not by running, but by either blaming those they serve or extraordinary circumstances, or by trying to pass responsibility to others. However, such evasions inevitably prove disastrous and have results far from those envisaged by the respective characters. By contrast, in Donadieu Hochwälder presents characters who accept the burdens placed upon their shoulders, despite considerable hurdles, and as a result, justice is seen to be achieved.

Despite all three plays having historical settings, the issues they raised at the times of their premières in the late 1940s and early 1950s were strikingly relevant to recent European history. Der öffentliche Ankläger, in its presentation of the use of political terror to control a population and remove opponents of the regime, clearly evokes the period of the Third Reich, as does reference in the play to the monstrous use of the victims' hair and skin to manufacture wigs and leather $(I, 302)^{1}$. Despite this, the play's historical setting allowed for a more dispassionate approach than a contemporary milieu would have allowed, giving the play greater universality than might otherwise have been achieved. Nevertheless, Hochwälder concedes the thematic links to the Third Reich, while emphasizing the play had a wider target: "Natülich hatte ich Freisler ${ }^{2}$ vor Augen, aber ebenso die älteren Mord-Staatsanwälte der Sowjetunion [... $]^{\prime 3}$. Hochwälder also deliberately chose the period of the French Revolution, a period that continued to fascinate him $^{4}$, because of the link he saw between it and recent events in Europe:

1 Although it should be noted that Büchner in his drama set during the French Revolution, Dantons Tod (1835), has members of the public also suggest such gruesome uses for human skin and hair. Cf. Georg Büchner, Dantons Tod, In: Werke und Brief, 5. Auflage, (München: Deutscher Taschenbuchverlag, 1984), 13 and 66.

2 Roland Freisler (1893-1945) served in the Third Reich as Permanent Secretary in the Ministry of Justice before becoming President of the People's Court in Berlin in 1942. He conducted numerous trials against opponents of the regime, of which $90 \%$ resulted in the death penalty or life imprisonment, and in which he launched brutal and denigrating attacks on the accused. Cf. Alisa Schapira, "Freisler, Roland", Das große Lexikon des dritten Reichs, Hrsg. Christian Zentner und Friedemann Bedürftig, (München: Südwest, 1985), 191-192.

${ }^{3}$ Fritz Hochwälder, in: Anonym, "Der offentliche Ankläger", Neue Warte am Inn [Braunau], 4. Dez. 1974.

4 As is reflected in his later play Die Prinzessin von Chimay, and by reference to further research on the period in the essay "Kann die Freiheit überleben?" (Im Wechsel der Zeit, 103-131), which resulted in the uncompleted typescript "Der Feldzug. Schauspiel in drei Akten". 
Zum ersten Mal in der Geschichte nahm damals der Terror Formen an, die er erst wieder in unserer Zeit zeigt. Die dirigierte Justiz verübte nämlich Verbrechen nicht mehr im Auftrag eines einzelnen, eines Tyrannen, einer Despotie - sondern verwendete Begriffe, die bis dahin nicht im Schwange waren, Begriffe, welche die Revolution geschaffen hatte: Volk und Nation. So wurde das Blut von Unschuldigen im Namen des Volkes vergossen $[\ldots]^{5}$.

The play also avoids the danger of being too zeitverbunden through its evocation of other literary works, as has been observed by several critics. The most striking influence, and one Hochwälder readily acknowledged, is that of Sophocles' Oedipus:

Erstmals kam mir die Idee zu diesem Schauspiel, als ich vor langer Zeit in einer Ausgabe von Friedrich Schillers Briefen auf den Satz stieß: "Ich gäbe zehn Jahre meines Lebens für einen Stoff wie den Oedipus Rex". Der betreffende Brief [...] schilderte die schier unüberwindlichen Schwierigkeiten eines derartigen Stoffes jenseits der griechischen Mythologie. Ich teile [sic] die Überzeugung des großen Dramatikers, bis ich eines Tages, Mitte 1946, einen Zeitungsartikel las, der sich mit der dubiosen Persönlichkeit des Öffentlichen Anklägers beim Französischen Revolutionstribunal beschäftigte [...] blitzartig kam mir der Gedanke ihn frei nach dem Ödipus agieren zu lassen: ein hoher Richter, der unwissentlich gegen sich selbst verhandelt ${ }^{6}$.

Hochwälder later returns to this Greek model in Der Befehl, as Martin Esslin has noted ${ }^{7}$. However, while Fouquier may act unknowingly against himself, his calculating behaviour does not lend itself to comparison with Sophocles' tragic hero, whose motivation is far more altruistic and is scarcely likely to provoke questions about tragic guilt ${ }^{8}$.

The plot also suggests the tale of another corrupt judge hoisted by his own petard: Richter Adam in Kleist's play, Der zerbrochne Krug ${ }^{9}$. Certainly, Hochwälder was a great admirer of Kleist, considering him and Ferdinand Raimund the greatest of German-speaking dramatists ${ }^{10}$.

5 Fritz Hochwälder, "Der öffentliche Ankläger", Programmheft des Schloß Theaters, Celle, Nr. 3, 1989/90. This concern with the potential misuse of ideology and the dangers of utopian dreams will be examined in more detail later, and has great relevance in plays such as Donnerstag, Lazaretti oder Der Säbeltiger and Die Biirgschaft.

6 Fritz Hochwälder, "Der Autor zum Stück", Programmheft des Stadtheaters Klagenfurt, Nr. 2, 1988/89.

7 Martin Esslin, "Nachwort", Dramen III, Von Fritz Hochwälder, (Graz: Styria, 1979), 305.

8 A solution to the question of where the tragic guilt lies in Sophocles' play is, in fact, suggested by Fliess in Lazaretti oder Der Säbeltiger: "Ödipus handelt!" (III, 273).

9 Bortenschlager, Der Dramatiker Fritz Hochwälder, 103; Piero Rismondo, "Leider noch nicht historisch", Die Presse [Wien], 24. Sept. 1965; M. W. Dworzak, "Die Revolution frißt ihre eigenen Kinder", Passauer Neue Presse Niederbayerische Presse, 7. Okt. 1982. 
The picture of an official in charge of a brutal regime of justice has also led to parallels being drawn with Kafka's short story "In der Strafkolonie"11, in which the administrating officer is himself killed by the machine he controls. Fouquier's repeated references to being part of a greater machine [see below] reinforces such an analogy. But this comparison cannot be taken too far since Kafka's officer is a willing and knowing victim, unlike Fouquier, and with him his terrible machine is also destroyed, something which is hoped for but cannot be assumed with the fall of the Public Prosecutor.

The setting of the French Revolution also demands comparison with Büchner's play, Dantons Tod, and this proves particularly rewarding ${ }^{12}$, since Hochwälder's views on the origins of the use of state terror in the French Revolution strongly echo those of Büchner's Danton:

[...] So wurde das Blut von Unschuldigen im Namen des Volkes vergossen - zu Anfang, als die junge Republik von Invasion bedroht war, mit einem gewissen Recht ${ }^{13}$. Aber die feindlichen Armeen wurden geschlagen, der Schrecken verlor seine Legitimation - und wurde nicht nur beibehalten, sondern noch verstärkt ${ }^{14}$.

Danton justifies his involvement in the September Massacres with the external threat to France ${ }^{15}$, but goes on to criticise Robespierre's continued use of the Terror after this threat had passed: "Wo die Notwehr aufhört fängt der Mord an, ich sehe keinen Grund, der uns länger zum Töten zwänge"16.

The motif of trembling, which is used effectively in Der öffentliche Ankläger to convey the all pervading fear generated by the Terror [see below], may also have its roots in Büchner's play. Büchner's villain of the piece, Robespierre, arguing in front of the Convention for the continued use of Terror declares: "[...] wer in diesem Augenblicke zittert ist schuldig, denn nie zittert die Unschuld vor der öffentlichen Wachsamkeit" ${ }^{17}$, a statement that is echoed

${ }^{10}$ Hochwälder, Im Wechsel der Zeit, 26.

11 Vogelsang, “Das klassizistische Ideendrama Fritz Hochwälders”, 230; and taken up by Holdman, 48.

12 Hochwälder showed himself early on to be an admirer of Büchner, and in his youth managed to enrage school authorities by advocating, at a school literary discussion group, the importance of Büchner in any discussion of freedom in German literature [Richard Thieberger, "Fritz Hochwälder vor dem Anschluß", Gedanken über Dichter und Dichtungen. Essays aus fünf Jahrzenten. (Les textes et les auteurs. Cinquante années de réflexions sur la litterature), von Thieberger, Hrsg. Alain Faure, Yvon Flesch und Armand Nivelle, (Bern: Peter Lang, 1982), 267-274, 270; R. T., "Introduction", Donadieu. Schauspiel in drei Akten, by Fritz Hochwälder, ed. Charles B. Johnson (London: George G. Harrap, 1967), 11-12.

13 A comment worth noting by those who seek to present Hochwälder as an advocate of pacifism in the face of evil [see below].

14 Fritz Hochwälder, "Der öffentliche Ankläger", Programmheft des Schloß Theaters, Celle, Nr. 3, 1989/90.

15 Büchner, 37.

16 Büchner, 24. 
by Fouquier in Der öffentliche Ankläger: "Wer zittert, ist schon verloren" (I, 253). Significantly both Danton ${ }^{18}$ and Fouquier (I, 307-308), in the respective dramas, are reduced to trembling shortly before they are arrested.

Maria Holdman has drawn attention to the similar use of windows in the scene "Es ist Nacht" (II.5) in Dantons Tod and II.9 in Hochwälder's play ${ }^{19}$. In both dramas they are used as vehicles for sudden insight on behalf of the protagonists, where the horror of their former crimes momentarily reduces them to trembling in fear. She concludes that: "[...] In total contrast to Büchner's Danton, Fouquier, the tool of the tribunal, ignores the vision which might have saved him [..." 20 , and certainly while Danton is unable to use this insight to save himself, and initially defends his earlier behaviour, by the end of the play, unlike Fouquier, he does come to accept his own guilt and refuses to contribute any more to a Terror he knows to be wrong.

Indeed, Holdman might have taken this line still further, since Danton is not alone in grappling with his conscience at a window in Büchner's drama. Earlier Robespierre too is drawn to look on the outside world, after being challenged by Danton, and he too briefly questions his own behaviour. However, more like Fouquier in Der öffentliche Ankläger, he ultimately rejects such misgivings, telling himself: "die Sünde ist im Gedanken. Ob der Gedanke Tat wird, ob ihn der Körper nachspielt, das ist Zufall"21. Like the later protagonist of Hochwälder's play, he chooses not to dwell on such self-doubts.

In fact, both plays can be compared with certain aspects of another play: Carl Zuckmayer's Des Teufels General, to which Hochwälder would seem to allude when he dubs his protagonist: "Des Teufels Bürokrat"22. Both plays can be seen to address the issue of collective guilt in the Third Reich, albeit with seemingly different conclusions, since Zuckmayer would seem to reject the idea with the character Oderbruch, a heroic member of German resistance under the Third Reich, while in Hochwälder's play all seem to take on some guilt for the Terror, and act against their consciences ${ }^{23}$.

All three plays have protagonists who initially believe themselves to be indispensable, and therefore safe. Fouquier's belief that he is untouchable is based on the knowledge he has acquired of those in power, and which he could use at any time against them. Danton, despite his resigned cynicism about the

\footnotetext{
17 Büchner, 40 .

18 Büchner, 36.

19 Holdman, 55-58.

20 Holdman, 57.

21 Büchner, 26.

22 Fritz Hochwälder, "Der öffentliche Ankläger", Programmheft des Schloß Theaters, Celle, Nr. 3, 1989/90.

23 The difference in attitude of the two dramatists to the question of collective guilt is perhaps even more relevant in regard to Meier Helmbrecht, which categorically, if in allegorical form, condemns those who did not actively oppose the Nazi regime. Hochwälder's play [see below] was a relative failure, while Zuckmayer's drama, with its heroic portrayal of Harras and more ambiguous message on collaboration was highly successful, and undoubtedly more palatable to audiences in the immediate post-war period.
} 
direction the Revolution has taken, is confident that his enemies amongst the revolutionary leaders still need him: "Sie hatten nie Mut ohne mich, sie werden keinen gegen mich haben; die Revolution ist noch nicht fertig, sie könnten mich noch nötig haben, sie werden mich im Arsenal aufheben" ${ }^{24}$. He toys with the threat of death in conversation but clearly does not take it seriously, saying of his opponents: "sie werden's nicht wagen" 25 , until finally in prison he must concede he was wrong: "[...] ich dachte nicht, daß sie es wagen würden" 26 . Likewise Zuckmayer's General Harras, a man who is fully aware of the evil of the Nazi regime but does little actively to oppose it until the end, believes himself, at least in the first act, to be too important to the regime to be touched:

Schließlich wollen die Brüder den Krieg gewinnen - das heißt - sie können gar nicht mehr zurück. Und da gibt es nur eine Handvoll Leute, die an der richtigen Schraube drehen können und sagen: gewußt wo. Sie haben mich gebraucht - und sie brauchen mich jetzt erst recht ${ }^{27}$.

Zuckmayer's play, which even mentions Dantons $\operatorname{Tod}^{28}$, also features windows at moments of important revelation. This first occurs in Act I when Harras looks out and tells Olivia how he imagines the searchlights on the night sky are five fingers of a monstrous hand reaching over to destroy Berlin $^{29}$. As in Der öffentliche Ankläger, where the Seine is blood-red from the discharge of the abattoirs, there is a ready explanation for what he sees, and he rejects the notion that his sensitivity has anything to do with nerves, from which he boasts he has never suffered. Yet, it is an expression of his emotional state which alarms his companion. The imagery is repeated in Act II, when, upset after the confrontation with Pützchen, Harras goes to the window for air, and seeing the searchlights again, retreats full of fear: "Herrgott im Himmel. Ich habe Angst. Ich habe Angst. Ich habe Angst [... ${ }^{30}$. As happens to both Robespierre and Danton in Büchner's play, he is immediately disturbed by another character, and, like Fouquier in Der öffentliche Ankläger, he laughs off his fear. This time he acknowledges that nerves have something to do with it, but is not yet ready to follow Oderbruch's suggestion to take heed of them: "[...] man soll ihnen manchmal etwas Zügel geben. Sonst werden sie hartmäulig und warnen uns nicht mehr" ${ }^{\prime 1}$. He is again

24 Büchner, 23.

25 Büchner, 22, 30, and 35 .

26 Büchner, 45 .

27 Carl Zuckmayer, Des Teufels General. Drama in drei Akten (Frankfurt/M: Fischer Taschenbuch, 1973), 37 [Originally published 1946].

28 Zuckmayer, 116.

29 Zuckmayer, 99.

30 Zuckmayer, 124.

31 Zuckmayer, 125. 
drawn to the window in Act III, and once more it is at a highly emotional moment, as he has just been attacked by the newly widowed Anne Eilers for failing to do something against a regime in which he does not believe ${ }^{32}$. It is at this moment, it seems, that he recognizes who is responsible for the sabotage he has been ordered to stop, and he acts upon this, telling Oderbruch: "Ich spüre es - ahne es - mit all meinen Nerven"33. Unlike Hochwälder's Fouquier, but like Büchner's Danton, Harras is able to confront his own responsibility for his role in the crimes of the regime, and while unable to escape with his life, dies an honourable death.

The issue of personal responsibility, or rather the failure of individuals to accept it, is central to Der öffentliche Ankläger, and is portrayed as a key factor in the perpetuation of the Terror. Like the border guard in Der Flüchtling, Fouquier-Tinville, defends his role as Public Prosecutor in the regime as that of a conscientious official, reluctantly carrying out odious duties. However, just like the Grenzwächter, he is exposed as doing far more than just following orders, and is an essential cog in the machinery of oppression. The play goes further than Der Flüchtling, however, in exploring how political terror operates, for not just the Public Prosecutor stands accused of helping the regime: all the characters, to a greater and lesser extent, are guilty, either through misguided ideals or simply through fear and weakness, of contributing to the Terror.

Fouquier sits at the heart of the Terror, charged with quickly and efficiently dispatching those accused of working against the ideals of the Revolution. Such is the ruthlessness of the judicial process which he runs, that to be accused is to be found guilty, without recourse to defence, and, as he demonstrates in the opening scene of the play, the list of executions can be confidently prepared before the trials have even been conducted.

In this tumultuous world, even those in power cannot be totally secure, since the executions of Danton and Robespierre demonstrate the impartiality of the guillotine. As a result, an atmosphere of fear pervades Der öffentliche Ankläger, affecting all the characters that appear. This is visibly shown by the involuntary trembling that strikes all but Montané, and which becomes a Leitmotiv for terror throughout the play.

In the opening scene Fouquier reproaches his subordinate, Grébeauval, who has been shaken by his malicious teasing: "[...] zittere nicht! - Wer zittert, ist schon verloren. Hast du mich je zittern sehn?" (I, 253). Yet later, when they believe they have discovered that the secret victim is none other than Theresia's own husband, who once nearly delivered her to the guillotine, Grébeauval again cannot control his shaking (I, 282).

It is this same fear which Fouquier exploits in the two false witnesses he needs to conduct the trial. He knows enough about Héron's past to bully him into submission and soon has him quaking in fear (I, 291), and while it takes a little longer for Fabricius, he too is reduced to a trembling and pliant tool in the Prosecutor's hands (I, 309).

\footnotetext{
32 Zuckmayer, 143-146.

33 Zuckmayer, 148.
} 
Those in power are not immune to fear either. Tallien has a past which may at any moment come back to haunt him, and throughout the play he cannot conceal his dread of Fouquier, trembling in front of his wife and openly doubting their plan to bring him down (I, 269), and, at the last minute, attempting to dissuade Theresia from their dangerous course of action (I, 313314). At the trial he almost completely succumbs to his fear (I, 316-320). Likewise his accomplice, Theresia, who remains resolute throughout in her determination to destroy Fouquier, cannot stop herself shaking when confronted by the ruthlessness of the power her victim wields $(\mathrm{I}, 304)$.

Most significantly of all, Fouquier-Tinville himself is shaken by the monstrosity of his work. When he sees the Seine running red with blood from the abattoirs he is suddenly overcome by fear and shakes for the first time like his victims (I, 307-308). Yet, despite his earlier words to Grébeauval, he does not take heed of this warning revelation and continues to pave the way to his own destruction ${ }^{34}$ [see above].

The only character not reduced, at least once, to trembling ${ }^{35}$ is the former judge, Montané, and this may be explained by the fact that he has avoided taking on any guilt himself for the Terror around him. As a judge he refused to act against his conscience in the case of Charlotte Corday, in doing so almost condemning himself to death. Yet he is unrepentant and would do the same again (I, 261). What makes Montané different from the others is that he has remained true to his conscience and not acted merely from expediency or a desire to save his own skin. He still has faith in others, although this may be misplaced, since Fouquier takes great delight in telling him he knew each of his movements when he was in hiding after the Corday affair $(I, 262)$. But it is this faith and a belief in justice which has so far prevented him from falling victim to the fear that afflicts the other characters. He reveals this faith to Theresia, while admitting it has been tested by the lack of progress she and the successors to Robespierre have made in removing the Terror $(\mathrm{I}, 299)$. Nowhere is the genuineness of his principles more clearly demonstrated than by his response to being handed his file by Fouquier, the very evidence that could deliver him to the guillotine: "Freiheit... Freiheit... für mich - Freiheit für einen einzelnen... der das Glück der Fürsprache erfährt [...] Und wann kommt die allgemeine Freiheit?" (I, 299). It is also significant that Fouquier hands him the dossier before Montané agrees to his request, indicating that the master manipulator knows that fear cannot persuade him, as it has Fabricius, another opponent of the Terror, to do the Public Prosecutor's bidding.

Yet, if Montané's conscience has remained clear until this point, Theresia's

34

Daviau ["Der innere Konflikt [...]", 913] overlooks this scene when claiming there is no inner struggle between good and evil in Fouquier, whom he sees as a character with no redeeming characteristics. Brief though the scene may be it does show that the protagonist, for a moment at least, is aware of the magnitude of the horrors of his office. Cf. Holdman, 55. [See above].

35 Even the executioner, Sanson, the most comical character in the play and a parody of the decent craftsman who takes pride in his work, finds the enormity of his bloody task almost too demanding, and complains of trembling (I, 259). 
impassioned plea to help her strike a telling blow against the Terror persuades him to sign the blank arrest warrant; something he knows to be wrong: "Ich werde zufrieden sein, wenn unserer Zeit die Freiheit erkauft werden kann mit diesem Verbrechen - das mein erstes ist" ( $I, 303$ ). But this first step into crime is a dangerous one as Fouquier tells Theresia: "[...] wenn man mit einem Fuß ins Verbrechen gestiegen ist, nimmt es den andern von selbst hinein" (I, 305). It is the same warning he gives to Montané with his last words: "Gib auf deinen andern Fuß acht! - Montané!" (I, 325) ${ }^{36}$. The next scene emphasizes just how vulnerable Montane will be in future when the triumphant Theresia decisively insists that he will do her bidding (I, 325). The inevitable conclusion must be that, having committed his first crime, he too will soon suffer from the contagious tremors ${ }^{37}$.

Fouquier-Tinville's role in this world of fear is to run the machine of the Terror: the guillotine. Far from a bloodthirsty monster he is an ambitious bureaucrat who claims simply to carry out his orders efficiently ${ }^{38}$. Despite his bloody duties, for much of the play Fouquier is at pains to divert personal responsibility, arguing that he is a "Sklave [seines] Amtes, sonst nichts!" (I, 271). He is even able to express regret at the execution list he has prepared:

Wir haben monatelang mit den Angeklagten zusammen gearbeitet - es sind Freunde von mir darunter. Schade, daß sie jetzt in den Sack niesen müssen. Kann's aber nicht ändern. Ihre Vernichtung ist befohlen. [...] Man führt durch, was einem befohlen wird - alles andere ist von Übel.

Such sentiments are repeated throughout the play, often combined with the justification that failure to carry out his orders would have had fatal consequences for himself (I, 254, 266, 267, 271, 272, 276, 297, 306). This defence is often coupled with imagery which portrays Fouquier as merely one part of a much larger machine [see above], thus still distancing himself from responsibility on a personal, human level. He tells Montané: "Ich war immer nur das Beil!" (I, 266), describes the process to Theresia thus: "Es fehlt nur noch ein einziges Rad in der Maschine, wenn ich das einfüge, läuft sie von selbst [...]. Auch ich bin von diesem Augenblick an nichts anderes mehr als ein Teil dieser Maschine, sie nimmt mich mit [...]" (I, 297), and warns Grébauval of the dangers of falling under the wheels of this automaton (I, 276). His task it would seem is just to organize things so that the machinery is well-oiled $(I, 306)$, and he is not to blame for that which the machine, of

36 Montané might look justifiably perplexed by this advice since he was not privy to the earlier conversation between Fouquier and Theresia!

37

Cf. Holdman, 42. Daviau ("Fritz Hochwälder", 250) fails to recognise the significance of these passages when he tries to argue that Montané is able to keep his integrity despite his crime because "[...] Fouquier is clearly guilty".

38

This is a defence which Maria Holdman erroneously [see below] accepts at face value stating: "Fouquier's moral and psychological existence seems to be rooted in a world where reality depends wholly upon precise, flawless response to an order" [52]. 
which he is part, has been ordered to do:

Ich - schrecklich? Nicht die Spur! - Gib mir ein gutes Gesetz und maßvolle Befehle - und du hast in mir einem gewissenhaften Beamten, der keinen Finger breit davon abweicht! Gib mir blutige Befehle - und ich werde zum Satan!

But the Public Prosecutor goes even further than just claiming to follow orders conscientiously, arguing that for as long as possible he fought against the terrible measures he was ordered to carry out. His most noble gesture, has of course been to save Montané and Fabricius, although both prove more use to him alive than dead, and this despite his observation: "Vom Lebensretten lebt man nicht - aber man stirbt manchmal dran..." (I, 263), a comment more true than he can yet realize. The magnanimity of saving Montané is, however, lessened by the admission that his friend's death was not "lebenswichtig" for Fouquier (I, 263).

He goes on to tell Montané that having taken on the job of Public Prosecutor from necessity, since he was one of many starving lawyers, he fought the Terror until he himself became threatened:

Ich habe mich gegen diese Maschine gewehrt, solange ich das konnte, ohne mich selbst in Gefahr zu bringen. Ich protestierte im Germinal, ich protestierte im Prairial ${ }^{39}$. Der Ausschuß jagte mich weg: "Mach zu - oder dein eigener Kopf fällt!" Gut. Ich habe den Schrecken in eigener Person vertreten - aber kommt der Schrecken von einem einzelnen? [...]

Furthermore, Fabricius, another character who clearly opposes the Terror, while unable to escape its web of fear, has compiled a list of actions to help a threatened Fouquier, which should demonstrate the Prosecutor's dislike of the regime and the efforts he made to help its victims (I, 285-286). Such proof of his good side clearly pleases Fouquier, but also draws from him a confession: "Da soll noch einer kommen und behaupten, ich sei ein Ungeheuer! [...] Aber ich kann dir nicht verschweigen, mein Bester, daß ich auch allerhand Leute übel eingetunkt habe [...]" (I, 286).

Fouquier saves his most impassioned declaration of his dislike of the Terror he serves for Theresia, from whom he desires a position on the commission charged with writing the new constitution:

FOUQUIER: Ich habe lange genug auf eine Gelegenheit gewartet die es mir gestattet, kehrtzumachen. Es ist mir spät zum Bewußtsein gekommen, was eigentlich aus mir geworden ist. Als ich zur

${ }^{39} \mathrm{He}$ is referring to popular Parisian uprisings against the regime in April and May of 1795 . Both proved unsuccessful. The real Fouquier-Tinville had been executed before the Prairial protests took place. (Germinal, Prairial and Thermidor were all months of the Revolutionary Calendar from which many significant events of the Revolution took their name). 
Besinnung gekommen war - saß ich auf dem Kutschbock eines Höllengefährts. Unmöglich abzuspringen - während dieser rasenden Fahrt. Um mich am Leben zu erhalten, um nicht zu Tode geschleudert zu werden, mußte ich den Karren zu immer irrsinnigerem Tempo antreiben. Die Macht wollte es so, ich hatte keine Möglichkeit - ihr pari zu bieten. Jetzt endlich ist der Augenblick gekommen, da ich einhalten kann, ohne mich selbst zu gefährden. Ich fordere zweierlei: daß mir mein Lohn gewiß ist und daß morgen schon, nach diesem letzten Prozeß, im Konvent der Angriff gegen das Prairialgesetz gemacht wird!

\section{Pause.}

THERESIA: Beides verspreche ich Ihnen! Sie werden Ihren Lohn bekommen und sofort danach fällt der Schrecken!

The dramatic irony in Theresia's response cannot be lost on the audience, but the unsuspecting protagonist continues to portray himself as the reluctant victim of an onerous task, which has left him "sterbenssatt" and for which he has "[...] bezahlt - bis an den Rand des Bankerotts!" (I, 305).

Such sentiments might lead one to have some sympathy for the Public Prosecutor. Alan Best sees him as "[...] a man with feelings who would like to be humane, but who has been robbed by the machine he serves. He has been robbed of any capacity for individual thought [...]"40. However, Daviau is closer to the mark, when he comments: "Despite his protestations of objectivity in carrying out his duty Fouquier is not simply an unfortunate individual trapped by circumstances in an unpleasant job. The enthusiasm that he displays for his job carries him beyond duty into guilt $[\ldots]^{\prime 41}$. A closer examination of the play shows that Fouquier's claims to be both humane and simply to be following his orders are clearly false, indeed his guilt stems from far more than over-enthusiasm.

Firstly, his words must be treated with caution since his claims of disliking the bloody task he has been given are made to people who are opposed to the regime; Montané and Theresia. Throughout the play he shows himself to be a master of human manipulation through his shrewd dealings with the executioner Sanson (I, 256-260; 293-295) and the witnesses Héron (I, 289-293) and Fabricius (I, 283-289; 308-310). In each case, he adopts quite different psychological tactics, always achieving what he wants. It is therefore logical to assume that the comments he makes to Theresia, now a powerful political figure, and Montané, who will also prove useful to him, are consciously designed to portray a sympathetic image of himself. Similarly, by taking part in the Germinal and Prairial protests, as well as allowing the likes of Fabricius to learn of his dissatisfaction with his job, he is providing material for his own defence, should the regime fall. There is no one in a better position to know the vulnerability of individuals, regardless of their position, than the Public

40 Best, 52.

41 Daviau, "Fritz Hochwälder", 249. 
Prosecutor who has delivered so many to the guillotine, and he uses this knowledge and shrewd psychological manipulation to protect himself.

When Fouquier does not feel obliged to adopt a certain standpoint for the benefit of his company, he demonstrates more than a little pride and arrogance in his position. He can brag to Grébeauval that it is he who has delivered all from the king to Robespierre to the guillotine, and promises to rescue his secretary should he have made any careless statements $(I, 253)^{42}$. Like the border guard in Der Flüchtling, with his list of names, through his cunning manipulation of people and material Fouquier goes far beyond reluctantly serving a regime in which he does not believe; his skills are an essential part of the administration of the Terror.

Furthermore, believing himself to be indispensable, he uses his office for his personal benefit, and this behaviour belies the claim of only carrying out his duty. Confident of his own importance, he is sure he is untouchable, and it is this fatal weakness that will lead to his downfall:

Wer außer mir beherrscht dieses Gesetz, wer? Wer kennt alle seine Kniffe, wer befiehlt dem Scharfrichter, den Gendarmen im Justizpalast, den Zeugen und Spitzeln, wer wird von der Geheimpolizei immer zuerst bedient? [...] Solang das Prairialgesetz besteht, braucht man mich. Solang man mich braucht - kann man mir nicht an den Leib. Braucht man mich aber nicht mehr - dann ist auch die Waffe, die mich umbringen könnte, unbrauchbar geworden - da ich der einzige bin, der sie führen kann.

(I, 267)

He has used his office to protect and further himself, and it is this motivation, rather than any desire to see the end to the Terror, that leads him to go along with Theresia's plans, since she is "die Macht von morgen" $(\mathrm{I}, 276)$ and "[ihr] dienen - das heißt, sich selbst dienen" (I, 282). When he believes he has discovered that Theresia wishes to bring down Tallien, he sees the chance to secure his position in a post-Terror world, which would have no need of his present services: "Wenn es mir gelingt - werde ich dort landen, wohin ich längst gehöre!" (I, 283). Again, the dramatic irony of such statements is unmistakeable.

To the very end Fouquier has complete confidence in his own abilities to advance and protect himself, and, echoing his earlier warning to Grébeauval about succumbing to fear, can tell his underling: "Es gibt nur eine Göttin - die Vernunft! Wer in Furcht verfällt durch Zeichen und Gesichte, der ist ein Narr, dem es zu sterben beliebt [... " $(I, 311)^{43}$.

42 Indeed, even in these scenes with his subordinate, Fouquier can be seen to be carefully adopting a role for Grébeauval's benefit: both impressing upon his underling his power and the importance of obedience to orders, for Grébeauval receives his from Fouquier.

43 Hochwälder may here also be indirectly attacking the ideas and theories of the Enlightenment, particularly those of Rousseau, whom Hochwälder harshly attacks in his essay "Kann die Freiheit überleben?" [Im Wechsel der Zeit, 103-131], which elevated reason above all else. During the Revolution there was a strong de-christianization movement, born from strong anti-clerical sentiments, which culminated in the so-called Cult of Reason, which, 
Despite Fouquier's repeated claims that he is only carrying out orders, it is his previous failure to carry out his duties to the letter that enables him to lay the trap for himself. Had he followed orders, Montané would now be dead, but Fouquier deliberately chose to disobey his instructions, although careful to have proof that he tried to carry them out $(I, 262)$. Likewise, he has saved Fabricius from the guillotine, when he refused to testify falsely against Danton, and now wishes to call that debt in (I, 285). Most importantly of all, he shows himself to be corrupt in his dealings with Héron. While bullying his hapless victim into bearing false witness against his unknown victim, he reveals that he executed Héron's former wife on false charges of conspiracy after having been bribed by Héron to do so (I, 290-293). It is also clear that it is not just Héron from whom he has taken bribes, since, as he admits to Theresia, his wealthy "clients" have not left him wanting for money (I, 297).

Such activities betray the fact that Fouquier is a far from diligent performer of orders, and he has readily bent the rules when it was to his advantage, as he is prepared to do for Theresia. Clearly he is a man responsible, at least in part, for his actions, despite his efforts to pass such responsibility on to those above.

However, in one respect Fouquier is correct in refusing to accept responsibility for the Terror, despite his position as its chief administrator. It is the failure of individuals in general to accept responsibility for their actions which allows the reign of fear to prosper. As all try to protect themselves in a constantly changing political environment, there are few who do not have something to hide in their pasts. As Fouquier observes when trying to ascertain who Theresia's intended victim is: "Es scheint überhaupt nur Verdächtige zu geben. Im Grund ist es gleich, wer uns geliefert wird. Es gibt nur einen Refrain - und der heißt: verdächtig, verdächtig, verdächtig!" (I, 278). Héron and Fabricius demonstrate most clearly how fear can make individuals accomplices in crime, while even Montané, the most principled of the characters that appear, is corrupted by the Terror: his desire to see it destroyed leads him to consciously commit a crime.

In such a world, the concept of an upstanding citizen is ludicrous, as demonstrated by the comic appearances of the executioner, Sanson. Despite his bloody job he sees himself as a decent hard-working member of society, who carries out his orders and takes pride in his craftsmanship. He takes great offence at the caricatures that have appeared around the city suggesting he should execute himself; he does, after all, have his family name to think of (I, 257-258). He, too, claims to be no great supporter of the Revolution ( 1,258 ), but has nevertheless continued to carry out his task to the point of collapse, despite decrying the loss of quality in his craft brought about by the demand for mass executions $(I, 259)$. With some persuasion he reluctantly continues to obey orders, while carefully avoiding taking on any responsibility which may later threaten himself: "Mein Beruf erzieht zur Vorsicht in politischen Dingen" (I, 260). Later, when he announces his retirement, he is persuaded to stay on

in 1793, led to Notre Dame being renamed the Temple of Reason. Cf. William Doyle, The Oxford History of the French Revolution (Oxford: Clarendon, 1989), 261. 
by the attraction of carrying out just a single execution: "Ein einziger! Daß ich das noch erlebe!" (I, 295).

The strongest evidence that the evil of the Terror does not rest with Fouquier alone is to be found in the most powerful opponents of the old regime: the Talliens. Tallien has the most to hide, for unbeknown to his wife, he was prepared to sacrifice Theresia to save himself. As Fouquier surmises, he probably only turned against the dictatorship of Robespierre when he saw it was his only chance to survive, and not to save Theresia $(I, 282)^{44}$. She is, in part, aware of his unsavoury past, telling him: "Wäre ich nicht in dein Leben getreten, wäre ich nicht in Gefahr gewesen - dann wärst du bis zum bittern Ende der gemeine Mörder, der Dieb, der Erpresser geblieben, der du vordem warst!" (I, 315). It is Tallien's guilt as well as his fear of the Public Prosecutor that explains his increasingly nervous state as the trial approaches, and he even contemplates the uses the Terror could be put to in their hands as an argument for stopping their attempt to bring down Fouquier (I, 313-315). Such behaviour amongst the new leaders hardly inspires confidence in the future.

Theresia herself, although nearly a victim of the Terror and one of its most ardent opponents, inspiring the likes of Montané $(\mathrm{I}, 299)$, is also prepared to make use of it for her own ends, even if her stated ambition is to destroy it with one last victim:

Solang Fouquier lebt, werden wir den Schrecken nicht los, der die Luft dieser Stadt verpestet. Man wirft uns vor, daß wir unsere Feinde von diesem Mann verfolgen lassen. Man behauptet, uns wäre der Schrecken ebenso unentbehrlich wie den Blutsäufern von gestern. Schon bieten uns die Kreaturen Robespierres ihre Dienste an, die Geheimpolizei läßt mich wissen, daß sie nun mir zur Verfügung steht. Niemand will Jakobiner gewesen sein - alles spricht mit Verachtung von Leuten, deren Freundschaft man noch vor kurzem suchte. Wir drücken die Hände, die mit dem Blut unserer Verwandten befleckt sind, auf Schritt und Tritt begegnen wir den Gestalten, die uns morden wollten - jetzt ziehen sie demütig den Hut... Für sie alle steht Fouquier - solang er lebt, sind wir unseres Lebens nicht sicher! Auf die Guillotine mit dem Ankläger - auch um den Preis eines Verbrechens! Er hat so viele Tausende begangen, daß uns dieses letze gestattet ist, mit dem wir ihn beseitigen!

(I, 269-270)

It is significant that, like Montane ( $\mathrm{I}, 303)$, she is aware that she is committing a crime, but seeks to justify this by the intended result, the destruction of the Terror. Certainly, there is no doubt she finds the work of the

44

Historians have indeed seen the toppling of Robespierre, in which the historic Tallien took part, as a reaction by men who felt it was the only way to save themselves. Cf. Doyle $277-$ 281; François Furet and Mona Ozouf (eds.), A Critical Dictionary of the French Revolution, trans. Arthur Goldhammer (Cambridge, Mass.: The Belknap Press of Harvard Univ. Press, 1989), 12-14. That Tallien signed Theresia's arrest warrant is also quite within the bounds of historic possibility, since he met her while she was imprisoned in Bordeaux. He and Claude Ysabeau were responsible for retaking the rebellious town which had attempted to resist Parisian rule and initially they ran the Military Commission set up there to punish the rebels. However, both were replaced by Robespierre for being too lenient. Cf. Doyle, 255-256. 
Public Prosecutor repugnant, and must cover her eyes when she sees him organizing those to be executed (I, 268), but her motives for his destruction may be personal rather than idealistic. She will never forget his face from personal experience:

Ich habe diese Augen oft gesehn, er weiß es nicht. - Unten in der Conciergerie. Fouquier kam mittags und abends mit den Listen. Er rief die Namen auf und zwinkerte dazu. Solange ich lebe, werde ich dieses Gesicht, diese Augen nicht vergessen. Auf der letzten Liste war mein Name!

When Fouquier asks why she wishes the destruction of the unnamed victim, she replies with an answer which makes revenge seem all the more probable, and, for Fouquier, Tallien the most likely victim: "Ich habe eine alte Rechnung zu begleichen. Aber das weiß er nicht" (I, 275).

But even if her motivation is purely noble, the warning Fouquier directs at Montané with his last words [see above], is equally, if not more so, applicable to her. By making use herself of the machinery of Terror, by using the same methods as Fouquier, such as the spy and informer Laboureau $(1,314)$, she not only compromises her own principles but also fosters the distrust, which had been the hallmark of the previous regime. Nowhere does this become clearer than in the last few scenes of the play. In Act III, scene 1, Tallien's fear, not only of Fouquier but also of his dominating wife, gets the better of him and the scene ends in mutual recrimination (I, 312-315). Her commanding attitude to Montané after the trial has already been noted and shows a woman clearly aware of the new power she wields (I, 325). Finally, in the very last scene (I, 326-328), when husband and wife fight over Tallien's file it becomes obvious that irreconcilable differences have been created between them, and the atmosphere of fear, which should have fallen with Fouquier, is still very strong. Information on others, such as that in the file, remains a powerful weapon, and the play ends with the married couple opposing one another as bitter enemies.

In light of this pervading atmosphere of hostility and fear, Fouquier's last gesture, as Maria Holdman has observed ${ }^{45}$, is very symbolic. Throwing hat, gown and sash to the ground Fouquier challenges those who have destroyed him to take up his office, for he knows the Terror will not die with him (I, 325). In this Fouquier shows a much greater understanding of the Terror than his opponents: the removal of one man will not be enough to undo the damage it has caused to the wider community, as Montané observed: "[Der Schrecken] sitzt uns allen in den Gliedern" (I, 299). This point is underscored when Grébeauval is quick to offer his services and congratulations to Tallien, after Fouquier's trial, and is reconfirmed in his position ${ }^{46}$. Little is likely to

\footnotetext{
45 Holdman, 42.

46 While the Terror is often considered to have ended with the fall of Robespierre and his followers, this did not stop their successors continuing to persecute their political opponents.
} 
change as the play concludes with the Talliens facing one another as fierce adversaries. As one reviewer observed: "Der Böse fällt, die Schuld bleibt und wird weitergereicht" 47 .

Fouquier's behaviour can only be morally condemned. He has consciously chosen to serve an immoral order for personal gain, and has committed numerous crimes for his own benefit, going well beyond the questionable defence of following orders. But guilt is not his alone, for the opponents of the Terror choose to act against their consciences in committing crimes they know to be wrong, justifying this by claiming it is the only way to end the Terror $^{48}$. However, once principles are compromised, the desired result may quickly become corrupted. Once again the play shows the familiar insistence on following one's conscience.

The issue of the individual's failure to take personal responsibility and the debate about collective guilt are also features of Meier Helmbrecht (1947). The protagonist's failure to deal with his son's misbehaviour and to prevent him from becoming a monstrous criminal is soundly condemned, and great emphasis is placed on the need not only not to partake in evil, but actively to oppose it.

As the full title of the play, Meier Helmbrecht. Frei nach Wernher dem Gärtner, acknowledges, the drama is based upon the thirteenth century story of the same name. However, Hochwälder makes significant changes to the original $^{49}$, and the play, first performed in 1947 , clearly alludes to recent European history. Hochwälder acknowledged as much in an interview on the occasion of the 1980 production of the play:

Ich habe in allen meinen Stücken politisch Stellung genommen. Und ich habe in vielen - wie Meister Helmbrecht [sic] oder Der öffentliche Ankläger - versucht, mit den Greueln und den Untaten der Nationalsozialisten abzurechnen. Die Hintergründe wollte ich aufzeigen und gleichzeitig

As one account puts it: "[...] the Thermidorian government decided on revenge as the way to put the Terror behind it" [Furet and Ozouf, 403].

47

Hermann Rainer, "Die weitergereichte Schuld", Neue Voralberger Zeitung [Bregenz], 8. Okt. 1988.

48

Cf. Gerlach, "Das Motiv des unterdrückten Gewissens [...]", 61-62. While Gerlach correctly highlights the way characters act against their consciences in the play he goes too far in claiming: "Macht und Unrecht existieren [...] nur, weil die Beteiligten gegen ihr besseres Wissen Moral- und Landesgesetze brechen" [62]. Clearly much of the behaviour in the play, while contributing to the furtherance of the Terror, in fact, is a product of the pervading atmosphere of fear the Terror has created.

A point which is not given enough attention by both Bortenschlager [Der Dramatiker Fritz Hochwailder, 95-96] and Schmitt ["The Theme of Responsibility [...]", 67], who in their rather cursory examinations of the play, claim the play closely follows the original story.

It is interesting to note the striking similarity in theme to that of the classical fable attributed to Aesop, "The Boy and his Mother" [Treasury of Aesop's Fables [New York: Avenel Books, 1973] 130-132]. In this tale the boy, far from being discouraged by his mother, is rewarded for petty theft as a child. As a result he grows into a criminal and is ultimately condemned to death for his crimes. On the scaffold he bends down as if to whisper a goodbye into his mother's ear only to bite it off in retribution for her failure to teach him right and wrong. 
appellieren, daß der Mensch für seine Freiheit kämpfen soll ${ }^{\mathrm{jU}}$.

In this light, the figure of Meier Helmbrecht can be seen as representative of many Europeans who did not approve of the National Socialists, but who did nothing to stop their rise to power, and in their impotence simply encouraged the fascists. Furthermore, the trial Hochwälder introduces to the third act, draws clear parallels to the debate about collective responsibility for the Third Reich, and emphasizes the need to face up to the mistakes of the past before the basis for a better future can be laid ${ }^{51}$.

The play's clear allusion to the Nazi past, might have contributed to the failure of what Hochwälder described as his "Nevergreen" 52 . This is what he suggests when he talks of its "fatale Aktualität" 53 at the première in 1947. Both Dieter Scho $\beta^{54}$ and Daviau ${ }^{55}$, lend credence to this view, although Daviau is incorrect when he claims the play was never produced again, since it saw productions in 1976, 1980 and 1981, and was broadcast as a radio play in 1986. It is a view shared by Ian Loram, with the added criticism that the play labours the point:

[...] it may well be that the public no longer wished to be so sharply reminded of the arrogance, the abuse of power, and the brutality that they had so recently experienced in actuality. Like Der Flüchtling, Meier Helmbrecht is a Lehrstiick. But the didactic element, despite Hochwälder's undeniably forceful and in part poetic language, is forced and too close to the surface ${ }^{56}$.

There can be little quarrel with Loram's view of the play as a Lehrstück ${ }^{57}$, but reactions to later productions, distanced by time from events still painfully in evidence to the Vienna of 1947, suggests the play's didactic message concerning the Third Reich is not as overstated as Loram suggests. Most critics of these later productions fail completely to make the connection ${ }^{58}$, often

50 Helmut Strutzmann, "Fritz Hochwälder zu Gast in Wien", Kleine Zeitung [Graz?], 17. Mai 1980: 20. Once again this would seem to belie the argument that Hochwälder advocates passive non-resistance to evil [see below on Donadieu].

51 This is an issue which, particularly regarding Austria, greatly concerned Hochwälder, and is very evident in the plays of the 1960s [See chapter 6].

52 Peter Vujica, "Fritz Hochwälder wörtlich", Neue Vorarlberger Tageszeitung [Bregenz], 29. Juli 1975.

53 Hochwälder, Im Wechsel der Zeit, 85.

54 Dieter Schoß, "Fritz Hochwälder", Österreichische Literatur des 20. Jahrhunderts, Hrsg. Horst Haase und Antal Mádl (Berlin: Volk und Wissen Volkseigener Verlag, 1988), 486.

55 Daviau, "Fritz Hochwälder", 248.

56 Loram, 11.

57 A description also employed by both Böhm [536] and Bortenschlager [Der Dramatiker Fritz Hochwälder, 100].

58 Anonym, "Gelungener Mödlagl-Beitrag zum Bauernkriegsgedenkjahr", Welser Zeitung, 
reducing it to a simple father-son conflict ${ }^{3 y}$, while the one reviewer to recognize the allusion to the Third Reich observes that what might have been relevant in 1947 is completely lost in $1981^{60}$.

Like Fouquier, the protagonist in Meier Helmbrecht fails to accept full responsibility for his position, and often takes the easy way out. It is also shown that while he may be guilty, he is not alone, and most of the other characters are also guilty of inaction, or acting against their consciences, rather than committing themselves to doing what is right. They, like Fouquier and the Grenzwächter, must learn to their cost, that such expediency can be selfdefeating.

In concentrating the action on the father figure, Hochwälder immediately differs markedly from the original Versroman. Johannes Ninck, in the "Nachwort" to his modern rendering of the original Dorfgeschichte, notes that it is not easy to determine, from the surviving manuscripts, after whom it should be named, since the son is at least as central to the story as the father. He opts for the father, since he is the sympathetic character ${ }^{61}$. Hochwälder's central character is very much the father, also a sympathetic, well-meaning figure ${ }^{62}$, but one who proves too weak to be able to act decisively, until it is too late.

From the very beginning, the warning signs of what is to come are made abundantly clear to the protagonist and the audience. Helmbrecht recognizes them himself, but seems unable to confront his son. He first appears with his neighbour Ruprecht, who is mentioned by Wernher but does not appear in the original $^{63}$, in a scene which serves to provide expositional detail about the son. Firstly, the protagonist chases off the Erzpoet, who having been invited there by the son, indicates the undesirable elements with which the younger Helmbrecht associates (I, 211). Then Ruprecht tells Helmbrecht that he will not allow his daughter to marry the son, although she loves him, because he is "aus der Art" (I, 212). He urges Helmbrecht to take drastic action: "Böses wächst auf in deinem Haus, Helmbrecht. Dagegen mußt du dich stellen als Meister und Vater!" (I, 213). But Helmbrecht is reluctant to use force against his own flesh and blood, and expresses the hope that he can win his son over

15. Juli 1976: Waltraud Dimsnik, "Bauerndrama in der Bergruine", Südost Tagespost [Graz], 13. Juli 1980, 2.

${ }^{59}$ Ursula Kammesberger, "Ein Vater-Sohn-Konflikt", Neues Volksblatt [Wien], 12. Juli 1976; Hermann Rainer, "Die Optik rettete Fritz Hochwälder", Volkszeitung [Klagenfurt], 29. Juni 1980, 11 and 19. Rainer went so far as to claim the play adds nothing whatsoever to the original by Wernher dem Gärtner, perhaps inadvertently betraying how unfamiliar he really was with the Versroman.

60

61 Johannes Ninck, "Nachwort", Meier Helmbrecht. Versnovelle aus der Zeit des niedergehenden Rittertums, von Wernher dem Gärtner, in neuem Reime dargeboten von Johannes Ninck (Stuttgart: Reclam, 1969), 60.

${ }^{62}$ For this reason one critic argues that it is difficult to accept his guilt because he arouses too much sympathy! [Kammesberger, Neues Volksblatt, 12. Juli 1976].

63 Wernher der Gärtner, Meier Helmbrecht. Versnovelle aus der Zeit des niedergehenden Rittertums, von Wernher dem Gärtner, in neuem Reime dargeboten von Johannes Ninck (Stuttgart: Reclam, 1969), 10 (z. 218-221). 
by appeasing him (I, 213).

However, he does show some willingness to discipline his unruly child, only to find both his wife and daughter begging him not to be too harsh (I, 214, 216). Furthermore, in another Hochwälder invention, fearing retribution and shame, Meier Helmbrecht allows himself to be manipulated into buying the son a knightly steed (I, 215-216). His position as head of the family now considerably weakened, he nevertheless tries to dissuade the son from leaving home and embarking on a path of crime, predicting, in typical Hochwälderian fashion, what will come to pass:

Dich reißt kein Wolf zutod auf einen Sprung. Dein kostbares Gewand werden dir ausziehn, die dich fangen, wie man dem schlauen Fuchs beikommt mit dem scharfen Eisen, das schlägt dir Hand und Bein ab; und nach dem Brauch wird man den Straßenräuber ums Augenlicht bringen und Blindekuh spielen mit dem Krüppel - so wirst du heimkommen und sprechen: Vater, wär ich doch blieben bei Axt und Pflug! (I, 217-218)

The son's response to this is to make a prophesy of his own, which will also come to pass: he will return and shower his family with gifts and earn the praise of all $(1,218)$. When his son rides off, Meier Helmbrecht does nothing to prevent it, arguing that it is already too late and blaming the women of the house for spoiling him. He claims that the only way to stop his son would have been to strike him down with an axe: "Hätt ich so wirken sollen gegen mein eigen Fleisch und Blut? [...] Hätt ich, um einen Narren aufzuhalten, ein Mörder werden sollen?" (I, 219) ${ }^{65}$. However, Helmbrecht, despite recognizing that it will all come to a bad end, only mournfully observes to his wife: "Weib - was haben wir für eine böse Saat getan: verderbt im Keim, der Trieb schon überwuchert von Unkraut um und um - - zu spät ist es zum Jäten und bald kommt der Schnitt" (I, 219) ${ }^{66}$.

Unprepared to take decisive action at the start of his son's infamous career, it is not surprising that Helmbrecht is equally impotent when the son returns. Initially in Act II he asserts his authority, admonishing the Apostelbruder and his band of peasants for the tales of terror he does not believe $(I, 224)$, and then telling his family and employees to leave the gifts brought by the armed men until he knows why they have come (I, 227). It is only when the son reveals his identity that control slips from Helmbrecht's grasp, as he again

64

While, as has already been seen, such prophesies often appear in Hochwälder's play here there is a correlation in the original. Cf. Wernher, 18-20 [z. 483-493; 499-506; 509-516; 522538]. Hochwälder does, however, introduce an original prophesy in the second act with the "Zinke" symbol drawn on the Helmbrecht house, which is interpreted by the Apostelbruder as a sign that the farm will be burned down [220]

65 Neighbour Ruprecht has already answered such questions: "[...] schneid den Arm ab, den dir die Viper vergiftet" (I, 213).

66 The agricultural metaphor is extended throughout the play by the seasonal setting of each act: the son starts out in spring, reaches the height of his dubious success in summer, and is destroyed in winter. 
fails to accept his parental responsibility. He must concede his earlier prediction was wrong (I, 229) and accept the humiliation of bowing before his son, now named Schlingdasland: "um Friedens willen" (I, 231-233) ${ }^{67}$, despite the Apostelbruder's demands that Meier Helmbrecht stand up to him. The act closes with Helmbrecht unable to do more than bury his face in his hands, taking no part in the celebrations $(I, 235)$.

In the final act events have come to pass as Helmbrecht had predicted, with the addition that his whole family and farm have also been ruined. He also finds himself on trial, accused of being guilty for his son's behaviour. At first, he does not even want to know about his son: "ich will nichts wissen von dem Ungut" (I, 237), and denies any responsibility for his son's actions. However, as the trial progresses, each one of his defences is exposed as self-deception. He has failed to discipline the child properly, or take action against him when he was older. He failed to stop him leaving to become a robber knight, and bowed to him rather than challenging him as a responsible father should have, when he returned. To make matters worse others warned him about his son, and he saw himself that it could only end badly (I, 237-244). Finally, Helmbrecht concedes his guilt to a list of sins which might well have been applied to many Germans and Austrians at the end of the war:

HELMBRECHT: Schuldig bin ich! Schuldig!

1. SCHÖFFE: Schuldig in der Wurzel am aufgewachsenen Unrecht.

2. SCHÖFFE: Schuldig fremden und eigenen Elends.

3. SCHÖFFE: Schuldig der Versäumnis.

4. SCHÖFFE: Schuldig der Schwachheit.

5. SCHÖFFE: Schuldig der Duldung.

6. SCHÖFFE: Schuldig der Feigheit.

But, if Helmbrecht is guilty of failing to fulfil the responsibilities of father and head of the household, he is not alone in contributing to the disaster that befalls all.

Clearly, the son's responsibility for his own behaviour is not lessened by Helmbrecht's admission of guilt, and he is punished in accordance with custom for his crimes $(I, 238)$. He appears at the end of the play having been blinded and minus a leg and hand ${ }^{68}$ ( $\left.I, 246\right)$, thus fulfilling his father's earlier dark vision.

The other family members are also culpable. Both Helmbrecht's wife and their daughter have dressed and armed the son as a knight, and were proud that he was different from other farmers' sons (I, 240), actively encouraging his arrogance. His wife is delighted when the marriage to Ruprecht's daughter is

${ }^{67}$ It is for similar reasons that the king in Esther attempts to justify unscrupulous behaviour, and, of course, the parallel can also be extended to both domestic and foreign opponents of the Third Reich who believed Hitler might be controlled through appeasement and concessions.

68 This is the same punishment as in Wernher's version, although later in the Versroman he is also hung by vengeful peasants. 
called off, for her son deserves better than a "Bauerndirn" (I, 214). She encourages her husband not to be harsh on the boy (I, 214), and has known about the son's deception in obtaining the horse, without saying anything to her spouse (I, 215). Later she shows little compassion for the fugitives from her son (I, 220), and along with her daughter eagerly accepts the gifts from him when he returns $(I, 227)$. Both women beg Helmbrecht to bow before his son, and are delighted when he does (I, 233). Finally, the daughter readily marries one of her brother's criminal companions (I, 233-234). Both, having encouraged the son through his childhood, are more than willing to share in his glory, albeit at the expense of others. Both are to share punishment when he falls: Helmbrecht's wife is placed in bondage, while his daughter has her hair shorn ${ }^{69}$.

But the opportunism shown by the Helmbrecht women is not a trait peculiar to them, but one that is demonstrated by the wider population within the play. In highlighting this general failing, two characters, who owe their origin entirely to Hochwälder, are important: the Erzpoet and the Apostelbruder. The play opens with the two travellers competing for the patronage of the staff at Helmbrecht's farm. Both have left the Catholic Church, but for entirely different reasons: the Erzpoet because he can live better from petty crime; the Apostelbruder from the religious conviction that the teachings of the Church are wrong (I, 209-210). This difference betrays fundamentally contrary outlooks on life: the Apostelbruder looks to the future and a golden age after evil has been rooted out in bloody struggle (I, 207-208), while the Erzpoet looks to the present and making the most of an unjust world, even if this means being unjust himself $(I, 210-211)$. Certainly, the vision of the future propounded by the Apostelbruder does not find much favour with the peasants:

APOSTELBRUDER: Die Heilszeit kommt nicht von selbst, sie muß erkämpft werden. Drum wird vorher Blut fließen in Strömen, die fruchtbaren Täler wird es erfüllen und hochsteigen bis ans Gebirge, Wehe und Jammer wird erschallen wie nie zuvor, gleichwie das reinigende Gewitter noch alles dahinbläst und schwemmt, was faul und schlecht und morsch ist - also wird's auch unter den Menschen ein Abwürgen und Hinsterben geben und ein riesiges Leichenfeld, eh der ewige Frieden anbricht und die Sonne für alles scheint, das da preisen wird den Namen des Herrn. Amen. [...]

FREIKNECHT: Wenn es vorher so wüst zugehn muß, dann soll alles lieber bleiben, wie es ist.

APOSTELBRUDER: Dann bist du ein Feind des ewigen Friedens!

FREIKNECHT: Meinetwegen. Die Hauptsache ist, daß es kein Blutvergießen gibt.

The unpopularity of such a message is not hard to understand, full as it is of

69 This punishment evokes the revenge enacted on women accused of fraternising with the enemy at the end of the war. 
violence and brutal punishment for sinners. But, as Act II shows, the apathy of the peasants and their natural propensity to avoid trouble if possible leave them vulnerable to attack from evil and ill-equipped to defend themselves. Indeed, the Freiknecht leads the chorus in support of the son when he returns, arguing to Helmbrecht: "Dein Sohn bringt uns Ehre, Gewalt und Macht" (I, 231).

Yet the Apostelbruder is the only character who consistently acts according to his conscience, and who does not take an expedient view of events around him. Although his message falls on deaf ears, a fact which does little to help feed him, he refuses to accept alms from the corrupting influence of the Erzpoet (I, 211). Later it is the Apostelbruder who attempts to organize the plundered peasants into resisting the reign of terror orchestrated by Schlingdasland. Again, he must struggle to convey his message to both those as yet unaffected and the victims of the robber knight: he is accused by both Helmbrecht and his wife of irresponsible scare-mongering (I, 220, 224), while his followers are tired and wonder if they might have been better off joining with their persecutors (I, 221-222). When Schlingdasland finally appears, the Apostelbruder is deserted by his followers and is left alone to challenge the marauder, a stand that nearly costs him his life (I, 230-233).

The Erzpoet, on the other hand, while showing that he is fundamentally good-natured, adopts a cynical, self-serving approach to life, summed up in his opening song:

Wie kommt man gradewegs durchs Leben?

Die wahre Lehre will ich euch jetzt geben:

Das Beßre tuend - Böses nicht.

Du sollst nicht töten, sondern ehebrechen.

Nimm nicht des Nächsten Habe, nimm sein Weib.

Merkt es der Nächste, sollst du also sprechen:

Ich tat es bloß zum Zeitvertreib.

Iß reichlich. Doch behalt das Wort:

Der Mensch lebt nicht vom Brot allein.

Ein jedes tu an seinem Ort,

Drum trinke viel, jedoch nur guten Wein.

Hölle und Paradies - das ist die Welt.

Des Armen Fegefeuer brennt hienieden.

Drum mehre stets dein Ansehn, Gut und Geld,

Dann ist das Paradies dir hier beschieden.

Nach oben buckle und nach unten tritt!

Beruf dich überall auf Seinen Namen!

Dann geht's dir gut. Dann gehst du Schritt für Schritt

Zu deinem Wohlstand. Und so sprech ich: Amen.

Such sentiments strike a chord with the peasants, who are also very ready to welcome the son back home, when they see it is to their advantage (I, 231, 233-235). It is such a philosophy that leads the Erzpoet to joining Schling- 
dasland, a life that certainly has more appeal than the hand to mouth existence endured by the Apostelbruder.

Cynical though his attitude is, he does show a kind side. He shares his bread with the preacher $(I, 210)$, although his subsequent behaviour does not earn him any thanks, and later through his intervention he saves the Apostelbruder from being killed by the peasants angered at his attack on their new benefactor, Schlingdasland (I, 232-233).

Yet his efforts to earn himself a comfortable life by dubious means are doomed to failure, and at the end he is reduced to being a guide for the now crippled son, helping him back to his destroyed home (I, 246). He ends the play as he started it, with a beating (I, 211,247), and his defence in the face of this second onslaught has the familiar ring of the Mitläufer, arguing that he was just doing his job:

Ich bin nicht schuld für ihn -! [...] Was hab ich getan? Fürs tägliche Brot gesungen und für mein Ansehn, da wären andere zu prügeln! Manchem hab ich das Leben gerettet durch Fürsprach und muß es jetzt ausbaden und Blindenführer sein, aber nicht lang!

The fate of the peasants in Helmbrecht's employ, who also shared the Erzpoet's view of life, has not been any better, carried off by those who exacted revenge for Schlingdasland's deeds (I, 236).

But for the final scene, the play comes close to being very pessimistic. Even the Apostelbruder, whose moral stance seems vindicated by events, appears to have had his faith shaken in the final act. Despite the defeat of Schlingdasland, he has seen enough to know that widespread evil remains and that the dawning of the golden age is not at hand:

APOSTELBRUDER: [...] Die Heilszeit ist ein schönes Ding und diese Welt ein sehr miserables.

HELMBRECHT: Mehr - weißt du nicht?

APOSTELBRUDER: Ich weiß mehr und könnte mehr sagen, aber es ist keine rechte Lust in mir und kein Auftrag. (Er nimmt seinen Wanderstab auf.) Ich weiß, daß der Teufel zur Hölle gefahren ist unter Donner und Gestank - und daß allüberall die Menschen des Teufels sind und daß nirgends in der Welt ausgerottet ist die Gewalt in der Wurzel und die Missetat erstickt im Keim [...]

In these last words Eileen Murphy sees a rejection of the idea of heaven on earth $^{70}$, as well as a rejection of "the use of retributive punishment and indeed violence in general" 71 , but this would seem to be reading too much into the

70 Murphy, 85. This point of view can find correlation in Hochwälder's essay "Kann die Freiheit überleben?" when he quotes Karl Popper's view "Der Versuch, den Himmel auf Erden zu verwirklichen, produzierte stets die Hölle" [Im Wechsel der Zeit, 121], but it is not strongly vindicated by the text of Meier Helmbrecht.

71 Murphy, 89. 
Apostelbruder's closing attitude and the events of the play reinforce his earlier position that evil must be dealt with firmly and swiftly before it grows. Certainly, the harsh sentence handed out to the son is not questioned in this final act, his crimes have been too great, and indeed this is reinforced when Helmbrecht finally turns his back on his wayward child, who returns home a cripple (I, 247). Helmbrecht himself may escape an additional sentence from the jury for his guilt, but this is not a rejection of retributive punishment, simply a recognition that he has already lost everything (I, 245).

The Apostelbruder serves a similar role to that of Schimke in Die Herberge, providing guidance on the right path to follow, but then at the end again taking up his staff to depart (II, 136): the way can be shown, but the individual must choose to follow it. Dramatically the Apostelbruder's reluctance to say too much in this last act, having represented for most of the play "das mahnende Gewissen"72, allows attention in the final scene to focus on the protagonist. He must now find a way forward for himself, and it is with him that the underlying optimism of the play lies. For it is he alone who has recognised his own guilt has finally rejected evil, represented by his son, and now, having faced the past, can look to rebuilding for the future. The play closes with him finding the head of an axe in the ashes of his farm, and with it he begins work $(\mathrm{I}, 248)^{73}$.

In Donadieu Hochwälder provides a sharp contrast to the characters of Meier Helmbrecht and Der öffentliche Ankläger, by presenting figures who, despite trying circumstances and personal considerations, do the right thing. Both Donadieu and Lavalette provide models of exemplary behaviour, and in so doing are shown to provide the basis for justice and a lasting peace amongst people of different persuasions. In relation to other Hochwälder plays, Donadieu is a triumph of decency.

However, while the black and white presentation of good and evil may succeed in the allegorical format of Meier Helmbrecht, in Donadieu the overall effect is to produce an impression of naivety. Donadieu's path from an obsessive desire to get even to a renunciation of vengeance only reaps its "just" rewards due to the contrived scenario that has in his religious opponent, Lavalette, an equally good man. The innocence of the play's assertion of common decency and tolerance undoubtedly led to the author's later dismissal of the play. It barely rates a mention in his essay "Über mein Theater", where he attributes the pathos it evoked in 1953 to the production and the times ${ }^{74}$, and in a letter, written in 1964, he describes it as "[...] ein Raubritterstück, das seit Jahren auf mich unfreiwillig komisch wirkt" ". His criticism of "that theatrical trifle about the Huguenots" is more extensive in lecture notes written in English:

72 Vogelsang, "Das klassizistische Ideendrama Fritz Hochwälders", 228.

73 There is no escaping the metaphor for the rebuilding of post-war Europe in Helmbrecht's actions.

${ }^{74}$ Hochwälder, Im Wechsel der Zeit, 85.

75 Fritz Hochwälder, Brief an Ernst Waldinger, 2. Dez., 1964. Dokumentationsstelle für neuere österreichische Literatur, Wien. 
[Donadieu] tells, I must confess it, a story innocent as a lamb and totally lacking in both salt and pepper. To be sure, the question of the desirability and the possibility of revenge and retribution is stated in three stage-worthy acts, but the answer that is given is a sabbatarian spirit that has no validity for our unruly times except to people who, in spite of everything, still believe in unctuous Sunday School tracts ${ }^{76}$.

Again Hochwälder uses a historical setting in which to present his moral dilemma, like Clelia in "Casa Speranza", turning to the seventeenth century French Huguenots ${ }^{77}$, inspired by Conrad Ferdinand Meyer's poem, "Die Füße im Feuer" "78. Thematically, the plot closely follows the story told in the poem, with the exception of additional characters and, most importantly, the introduction of the edict granting mercy to the Huguenots, which provides further pressure on the protagonist as he grapples with his desire for revenge. Hochwälder's view that the circumstances of its 1953 première, rather than the strength of the play itself, contributed to its success is supported by several later reviews. Despite its historic setting Kurt Kahl recalls it playing like a "Zeitsstück" in $1953^{79}$, and in dealing with themes such as the treatment of war criminals and the need for reconciliation it undoubtedly struck a chord at the time $\mathrm{e}^{80}$. The passing of time inevitably lessened the immediate connection with the Nazi past, a fact acknowledged by several reviews of later productions ${ }^{81}$, although it still earned praise for its relevance to the timeless and universal problem of persecution ${ }^{82}$.

For many, influenced by Donadieu's renunciation of revenge and the religious subject matter of the play, the drama has been seen as a pacifist statement and a rejection of resistance in favour of turning the other cheek $^{83}$. Eleonore Thun felt able to view the work favourably as the "moralische Anstalt christlicher

76 Fritz Hochwälder, "My Theater", typed notes, undated (but post-1968), Hochwälder NachlaB, Wiener Stadt- und Landesbibliothek, Wien.

77 Useful general historical background to the play is provided by Richard Thieberger, "Introduction", 11-41.

78

Conrad Ferdinand Meyer, "Die Füße im Feuer", Sämtliche Werke (Historisch-kritische Ausgabe), von Meyer, Bd. 1 (Bern: Benteli-Verlag, 1963), 382-384.

79

80 Cf. Richard Meister, "Religiöse Problematik in den Dramen Hochwälders", Maske und Kothurn, 2.1 (1956), 60-61.

81 Kahl, "Die Historie wird langsam historisch", Kurier [Wien], 24. Nov. 1980, 9; Karin Kathrein, "Wie aus Faszination fromme Erbauung wird", Die Presse [Wien], 24. Nov. 1980, 4; Franz Konrad, "Fritz Hochwälders Donadieu in Wien. Keine Stacheln mehr, sondern Patina", Neue Zeit [Graz], 27. Nov. 1980, 4.

82 Renate Wagner, "Die 'alte Garde' des Burgtheaters", Voralberger Nachrichten [Bregenz], 26. Nov. 1980, 21; Otto F. Beer, "Unterwegs zur Klassik", Suiddeutsche Zeitung [München], 3. Dez. 1980.

83

Cf. Meister, 65; Thieberger, "Introduction", 18-19; Loram, 9. 
Prägung"४4, while Arthur West, seeing it in a similar light, is highly critical:

[...] ein reichlich fragwürdiges Schauspiel, das in der Skala menschlicher Werte dem "stolzen Erdulden" unbedingten Vorrang gegenüber dem Kampf um Gerechtigkeit einräumt. Letzterer [...] reduziere sich ja auf Rache, und diese möge Gott vorbehalten bleiben, wobei erst solchem Begreifen der wahre menschliche Adel entspringe $[\ldots]^{85}$.

But the play is neither a call for a renunciation of resistance to evil or a pacifist plea, Du Bosc's bloody, but justified fate at the end testifies to that. Rather, it demonstrates the dangers of an uncritical belief in one's own cause ${ }^{86}$, which, as is the case with Theresia Tallien, may be used to justify immoral behaviour. Donadieu initially makes the mistake of equating his personal desire for revenge with justice, and fails to see the corruption that has entered his own camp. Lavalette, on the other hand, while rejecting the Calvinist doctrine of his Huguenot host, is an advocate of tolerance, and recognizes that there can be no absolutes, arguing that genuine justice must begin at home.

Donadieu's obsession with revenge is apparent in the first scene in which he appears, accompanied by the pastor, Berthelien, who with some exasperation reproaches this all-consuming desire: "Rache? Immer wieder Rache?" (II, 12). Despite the extremely precarious military position of the Huguenots, Donadieu cannot contemplate a cessation of hostilities until the man responsible for the massacre at Galargues is held to account:

DONADIEU: Man liefere uns die Bestie aus, die hier, in Galargues, unsere Frauen, Kinder und Greise hinmordete - erst dann kann wahrer Friede aus diesem Waffenstillstand hervorgehen - erst dann! [...] Bringt mir den, der hier, an dieser Stelle, mein armes Weib folterte und erschlug - setzt mich zum Richter über ihn - dann werdet Ihr mich zum Frieden bereit finden!

Pause.

BERTHELIEN tritt auf ihn zu: Es steht geschrieben: "Herr, verzeih ihnen, denn sie wissen nicht, was sie tun".

DONADIEU leise: Es steht geschrieben: "Aug um Aug, Zahn um Zahn".

Such single-mindedness blinds Donadieu to the true state of affairs and the morally questionable situation the Protestants find themselves in. He justifies dubious alliances with "Wir nehmen Waffen, wo wir sie finden" (II, 13) and turns to the murderous mercenary Tiefenbach for support in his claims that the situation is not as bad as it appears (II, 13-14). Nowhere is this blindness to reality more obvious than in the early exchange with Lavalette, who having

84 Eleonore Thun, "Moralist mit Theaterpranke", Wochenpresse [Wien], 26. Nov. 1980, 39.

85 Arthur West, "Vom Fall zweier Schlösser", Volksstimme [Wien], 4. Aug. 1976.

86 See Chapter 4. 
learned of the massacre acknowledges the brutality of war: "Der Teufel weicht nicht aus dieser Welt. Er wechselt bloß die Feldzeichen", only to have Donadieu retort self-righteously: "Die Hände der Unsern sind rein vom Blut Unschuldiger" (II, 18).

It is no surprise then that when Donadieu discovers that Du Bosc has inadvertently returned to the scene of the crime, he sees it as a sign from God to avenge the just who have fallen (II, 27). But in justifying his plans for revenge, he ironically foreshadows the decision he will have to make: sacrificing his desire for revenge for the benefit of his people and faith. Hence, when he toasts "Gerechtigkeit - oder Untergang!" (II, 39), while still thinking of justice as revenge, he signals the very choice he will soon be faced with, and when quoting David, he cannot yet know that, true to his name don à dieu, he will soon be putting his desire for justice in the hands of God:

Eine Unterweisung Davids [...] "Wirf dein Anliegen auf den Herrn; Er wird dich versorgen und wird die Gerechten nicht ewiglich in Unruhe lassen. - Aber, Gott, Du wirst sie hinunterstoßen in die tiefe Grube; die Blutgierigen und Falschen werden ihr Leben nicht zur Hälfte bringen. Ich aber hoffe auf Dich. - Amen"

It is left to his theological opponent and guest, Lavalette, to divert him from his path of vengeance. He shares Donadieu's belief that war criminals should be brought swiftly to justice, but argues that such justice can only be administered by those with the authority to do so (II, 42). He is also well aware that his side does not have a monopoly on brutality, and alludes to the crimes Tiefenbach has committed (II, 43).

The turning point comes when Donadieu learns about the edict, carried by Du Bosc, granting mercy to the defeated Huguenots, and must face the fact that carrying out his personal desires now has much wider ramifications, as Lavalette elaborates: "Entscheidet über Leben oder Vernichtung der Euern!" (II, 48). Confirmation that the Huguenots are at the mercy of the king's forces comes quickly when the peasants refuse to rally behind Donadieu (II, 49-50). Recognizing that all is lost, Lavalette, Nicolas, Berthelien, Barbe and Escambarlat all urge Donadieu to concede, and in doing so at least save the Protestant religion in France (II, 50-51).

The despair and bitterness of Donadieu's renunciation of his cherished aim are lessened by the presence of his daughter, a minor, undeveloped female figure representing, typically for Hochwälder, the voice of sweet reason and humanity. Earlier she has been terrified by her father's bloodthirsty rhetoric, countering his justifications for vengeance with "Mein ist die Rache, spricht der Herr" (II, 26), and later begging him not to dirty his hands with the villain's blood (II, 40). Now she offers a voice of consolation in his moment of despair:

DONADIEU: Wenn Satan Herr ist, will ich ihm in Gottes Namen dienen! [...] Raub, Schändung, Gewalttat, Brandstiftung, Folter an Wehrlosen - all das komme siebenfach über unser Haupt! - Vergebt, was ihr an 
uns begangen habt, verzeiht uns gnädig eure Schuld! - Seht: Abel flieht vor Kain nicht! Kain siegt! Kain übt Duldung, Mehr: Kain verheißt seinem Opfer Gnade! Auf die Knie vor Kain! [...]

JUDITH: [...] Schwer liegt Gottes Hand auf uns. (Sie nähert sich langsam Donadieu.) Und doch - es ist seine Hand!

DONADIEU nach einer Pause, langsam: - - Und doch - - ist es seine Hand! - -

This scene is seen by Meister as the first of two transformations that the protagonist undergoes. Here, he turns from an obsession with his personal grief and revenge to a concern for the wider community and his religion. Then in Act III, he experiences a further spiritual, religious transformation and renounces the right to resis ${ }^{87}$. Certainly, he is a changed man in Act III, and seems quite calm in his resolve, although the events of the night before have clearly taken their toll: "Er scheint uber Nacht gealtert, ergraut" (II, 56). In relation to the other Huguenots his role has reversed from the previous act, and now it is Donadieu who urges them to bow down to their enemy, and do as they are ordered, despite Du Bosc's heavy provocation (II, 56-61). He now seems to recognize that his earlier behaviour might have been flawed and that his belief that his desire for revenge was justified could have been wrong:

Ich erkannte: Gott ist auf uns gestürzt! - Wir glaubten, Ihn zu besitzen. Besaßen wir Ihn in Wahrheit? - Er schlägt uns jetzt den blutigen Degen aus der Hand - und spricht: Auserwählt habe ich euch - zum Leiden! - Und Satan speit uns an, tritt uns ungestraft mit Füßen... Sein Fuß geht über uns hinweg. Es ist ihm nicht erlaubt, zu siegen!

In his words to Escambarlat, there is an explicit rejection of violence:

Gewalt mag viel ausrichten. Sie mag unsere Kirchen zerstören, unsern Besitz rauben, uns aller weltlichen Ehren entkleiden - uns bleibt die unvergängliche Ehre, Kinder Gottes zu sein! - Demütigen wir uns, biegen wir uns, knien wir vor unsern Peinigern - in unsern Herzen wohnt Gewißheit, daß unser Bluträcher lebt!

(II, 61)

But it would be dangerous to overemphasize Donadieu's position here in relation to the overall play, and in doing so draw false conclusions about the rejection of resistance, as Meister and others have done. In his repudiation of Escambarlat's sudden and surprising act of bravery, Donadieu specifically refers to the position of the Huguenots to be able to resist, rather than making a universal maxim. They are quite simply unable to do anything but harm by offering further resistance in defeat. More significantly, in this scene at the very moment where Du Bosc admits killing Donadieu's wife and the others, and the protagonist "steht wie versteinert" (II, 61), Lavalette must intercede before anything else can happen. Any conclusions about the play must take

${ }^{87}$ Meister, 62, 65. 
into account this character, who plays such a dramatic role in the final act.

In his portrayal of the two sides of the historic conflict, Hochwälder is careful to present a balanced view. Both sides have their villains (Tiefenbach, Du Bosc), both sides have persecuted dissidents, as Escambarlat all too readily testifies $^{88}$, and both have their decent men (Donadieu, Lavalette). Of the latter Donadicu is the most interesting, undergoing a thorough test of his beliefs, while the character Lavalette is lumbered with the task of being upstanding and decent throughout. Nonetheless as a moral constant, he does provide an insight into the underlying values espoused by the play.

It has already been observed that as early as the first act, in contrast to Donadieu, Lavalette recognizes that crimes have been committed on both sides (II, 18). He repeats such sentiments later: "Satan führte unsere Kriege" (II, 48). He also shows himself to be a man of his word, promising swift justice for war criminals (II, 42), that Du Bosc will not be touched by the Huguenots (II, 23, 49), and that he will defend his companion: "Solang Thr Euch nicht gegen mich stellt!" (II, 23). He keeps his word on all counts, having ascertained for himself that Du Bosc is guilty he pursues and kills him when the villain raises his weapon in fear against him (II, 62), having prevented Donadieu from harming him.

In his pursuit of justice, as opposed to the revenge sought by Donadieu, he consciously sets out to prove to himself Du Bosc's guilt. He already suspects Donadieu is telling the truth about Du Bosc (II, 46), but since his companion denies having been there before (II, 49), he needs more evidence before he can act. It is this that motivates him to go along with Du Bosc's plan to provoke Donadieu so he can deal with him there and then, under the ostensible grounds of avoiding false accusations later. Du Bosc fails to recognize the danger in the plan implicit in Lavalette's words:

LAVALETTE: [...] Hört: - Reizt Ihr diesen Mann zur Unbesonnenheit, fällt er Euch im Jähzorn an - er, merkt: einzig und allein - er! -, dann... tut, was Euch beliebt!

DU BOSC: Ihr schützt ihn nicht?

LAVALETTE: Wenn euch gelingt, was Ihr vorhabt - rühre ich keine Hand! - (Näher:) Bloß eines vergeßt nicht: auch mein Ohr ist empfindlich...

DU BOSC: Kein Wort gegen Euch!

LAVALETTE: Ich habe Euch gewarnt. - Geht Euern Weg, Du Bosc!

Significantly, Lavalette does not take Du Bosc's hand when it is offered, a symbolic gesture of disgust already seen in Der Flüchtling, and, furthermore, insists that it is only Donadieu who may be provoked to violence ${ }^{89}$. That he

88 The dangers of unquestioning allegiance to a doctrine touched on in this play will be examined more closely in Chapter 4.

89

Lavalette's faith in his host's fundamental decency has already been demonstrated when he made the brave gesture of facing a man bent on revenge unarmed (II, 47-49). 
already guesses the outcome is shown when he tells Nicolas that one of the three horses waiting may be unsaddled, only two will be leaving (II, 55). The desire to see Du Bosc brought to justice also explains Lavalette's quick response, before Donadieu can react, as soon as his frustrated companion confesses to his crimes in a last attempt to provoke Donadieu (II, 61-62).

It is to the administrator of justice ${ }^{90}$ that the final important words of the play are given: "Nichts von Rache! [...] Recht tun heißt: sich reinigen vom eignen Bösen" (II, 62), words of which Hochwälder wrote: "Wenn diese Schlussworte im Hörer nachklingen, dann hat Donadieu die Aufgabe, die ihm der Autor zudachte, erfüllt" ". Justice, born by a determination to do what is right, rather than a desire for revenge, has been seen to be done. Furthermore, the way to a better, more just world is to start by examining oneself, and purging evil in one's own ranks; something which Donadieu, so consumed by his own grief and desire for vengeance had earlier been unable to do.

The play ends on the positive note of Escambarlat, who despaired when his brave stand was of no use against du Bosc (II, 61), enthusiastically taking ink to paper to record this message of hope (II, 62-63).

For all its earnest intentions, the happy ending, where all loose endings are tied up $^{92}$, is too contrived to be convincing. Lavalette is an almost one-dimensional model of decency and tolerance, while Donadieu's struggle with himself walks a tight line between pathos and bathos ${ }^{93}$.

In all three plays then, Der öffentliche Ankläger, Meier Helmbrecht, and Donadieu, there is a strong insistence on the need to take personal responsibility for one's actions and to be governed by one's conscience in resisting evil. In the setting of the French Revolution it is demonstrated how the widespread failure of individuals to accept such a burden allows evil to thrive, and how ultimately those same individuals are destroyed by it. Even those who justify immoral methods for achieving noble ends are shown to fall victim to the corrupting influence of evil.

Likewise, the medieval allegory that is Meier Helmbrecht, shows that everyone has a duty to accept the responsibility bestowed upon them, and must act in accordance with it. It also shows the necessity of acknowledging one's responsibility for past wrongs before a better future can be built.

In contrast to the first two plays, which show the consequences of evading responsibility, Donadieu offers a positive model of what may be achieved by the converse. Again, crimes of the past must be dealt with, in a just not vengeful manner, and by overcoming personal desires and listening to the voice of the conscience, great good can come out of evil. It is a laudable, if not convincing message.

90 It should be noted in response to those that have attempted to read a pacifist message into the play, that this justice, like that in Meier Helmbrecht, is swift and bloody.

91 Fritz Hochwälder, "Donadieu", typed notes, undated, Hochwälder Nachlaß, Wiener Stadtund Landesbibliothek, Wien.

92 Even Tiefenbach will be brought to justice (II, 51)

93 On the positive side, with the figure of Escambarlat, Hochwälder has created a genuinely successful Hanswurst figure, providing both humour and insight. Cf. Chandlee, 179-188. 
This last play also touches on another important barrier to following one's conscience: the subjugation of oneself to a greater authority, be it religious, political or ideological. Often, such authority can be invoked to justify what are base personal desires, but for several of Hochwälder's characters, there is the genuine, but ultimately misguided belief that the dictates of such authority must take precedence over the doubts of the individual. 